\title{
HUBUNGAN TINGKAT PENGETAHUAN IBU PUS TENTANG KANKER SERVIKS TERHADAP SIKAP UNTUK MELAKUKAN TES IVA DI DESA DELITUA LINGKUNGAN 3 KECAMATAN DELITUA KABUPATEN DELI SERDANG TAHUN 2015
}

\author{
Elisabeth Surbakti \\ Dosen Jurusan Kebidanan \\ Poltekkes Kemenkes Medan
}

\begin{abstract}
Abstrak
Menurut IARC, kanker serviks menempati urutan kedua dari seluruh kanker pada perempuan dengan incidence rate 9,7 \% dan jumlah kematian 9,3 \%. Sejak tahun 2007 hingga 2010, sebanyak 50.782 orang sampel diperiksa terhadap kemungkinan kanker serviks. Dari jumlah tersebut 18.010 (35,46\%) orang bersedia melakukan pemeriksaan IVA di Binjai, Medan, Sibolga, Padang Sidimpuan, Tebing Tinggi, Langkat dan Serdang Bedagai, 64,54\% yang tidak bersedia disebabkan karena kurangnya pengetahuan ibu tentang kanker serviks. Berdasarkan hasil pemeriksaan ditemukan 145 yang positif dan bersedia dilakukan pengobatan 88 orang. Penelitian ini bertujuan untuk mengetahui hubungan tingkat pengetahuan ibu PUS tentang kanker serviks terhadap sikap untuk melakukan tes IVA di desa Delitua lingkungan 3 kecamatan Delitua kabupaten Deli Serdang tahun 2015.Penelitian ini bersifat deskriptif analitik dengan desain cross sectional. Populasi penelitian ini adalah seluruh ibu PUS sebanyak 128 responden. Jumlah sampel 56 orang dengan teknik sistematic random sampling. Analisis data dengan univariat dan baivariat Hasil penelitian yang diperoleh pengetahuan baik 16,1\%, cukup 26,8\%, kurang 57,1\%. Sikap ibu positif 62,5\%, negatif $37,5 \%$. Hasil uji statistik diperoleh $\mathrm{p}=0,000<0,05$, artinya ibu PUS yang mempunyai pengetahuan baik dan cukup cenderung memiliki sikap positif atau bersedia melakukan tes IVA. Sedangkan pengetahuan kurang cenderung memiliki sikap negatif atau tidak bersedia melakukan tes IVA. Pengetahuan responden tentang kanker serviks mempengaruhi sikap ibu PUS untuk melakukan tes IVA di desa Delitua lingkungan 3 kecamatan Delitua kabupaten Deli Serdang, untuk itu diharapkan kepada tenaga kesehatan memberikan pendidikan kesehatan kepada ibu PUS tentang kanker serviks agar meningkatkan kesadaran ibu melakukan tes IVA.
\end{abstract}

Kata kunci : Pengetahuan, Kanker Serviks, Sikap, Tes IVA

\section{PENDAHULUAN}

Kanker serviks umumnya dikenal dengan penyakit kanker leher rahim. Jenis penyakit ini banyak dialami oleh kaum hawa (wanita) di negara berkembang. Menurut International Agency for Research on Cancer (IARC), kanker leher rahim menempati urutan kedua dari seluruh kanker pada perempuan dengan incidence rate 9,7 \% dan jumlah kematian 9,3 \% dari seluruh kanker pada perempuan di dunia. Dan berdasarkan IARC, insiden kanker leher rahim di Indonesia sebesar 16 per 100.000 perempuan (Depkes RI, 2008).

Menurut World Health Organization (WHO) tahun 2010, Indonesia merupakan negara dengan jumlah penderita kanker serviks yang tertinggi di dunia diantara berbagai jenis kanker yang menyebabkan kematian pada wanita di dunia. Setiap tahun terdeteksi lebih dari 15.000 kasus kanker serviks, sekitar 8000 kasus di antaranya berakhir dengan kematian (Info ceria, 2010).

Fenomena kejadian kanker leher rahim ibarat fenomena gunung es. Jumlah kasus yang timbul ke permukaan lebih sedikit dari kasus yang sesungguhnya. Karena banyak kasus kanker leher rahim yang tidak terdeteksi oleh petugas kesehatan. Hal ini disebabkan kurangnya pengetahuan ibu dan partisipasi ibu dalam mendeteksi dini kanker leher rahim, sehingga hal ini mengakibatkan wanita terlambat menyadari adanya kanker leher rahim (Indrapaja, 2008).

WHO (2006) dalam bukunya yang berjudul "Comprehensive cervical cancer control: a guide to essential practice" menyatakan bahwa keterlambatan wanita menyadari adanya kanker leher rahim meningkatkan angka morbiditas dan mortalitas kanker leher rahim, padahal kanker leher rahim sebenarnya dapat disembuhkan 100\% bila ditemukan sejak dini dan 
ditangani segera. Hal ini dikarenakan perjalanan infeksi HPV (Human Papiloma Virus) sampai menjadi kanker membutuhkan waktu yang cukup lama, namun kanker leher rahim ini tidak menunjukkan gejala kesakitan sama sekali pada stadium dini. Hal inilah yang mengakibatkan banyak wanita merasa tidak perlu memeriksakan diri sejak dini. Pada wanita yang tidak pernah melakukan deteksi dini, kanker cenderung ditemukan pada stadium lanjut, dimana kanker sudah sulit disembuhkan. Itulah sebabnya deteksi dini kanker leher rahim sangat penting dilakukan(Depkes RI, 2008).

Sejak tahun 2007 hingga 2010, sebanyak 50.782 orang sampel untuk diperiksa terhadap kemungkinan kanker leher rahim. Namun, Dari jumlah tersebut hanya 18.010 (35,46\%) orang yang bersedia melakukan pemeriksaan di tujuh Kabupaten/Kota masing-masing di Binjai, Medan, Sibolga, Padang Sidimpuan, Tebing Tinggi, Langkat dan Serdang Bedagai. Dan 32.772 (64,54\%) orang yang tidak melakukan tes IVA dissebabkan karena kurangnya pengetahuan ibu tentang kanker serviks dan deteksi dini kanker serviks. Berdasarkan hasil pemeriksaan terhadap 18.010 orang yang diperiksa, ditemukan 145 (0,6 \%)warga yang positif dan yang bersedia dilakukan pengobatan hanya $88(60,69 \%)$ orang (Chandra S, 2011).

Pemerintah telah melaksanakan program penapisan kanker leher rahim dalam mengendalikan kanker leher rahim. Departemen Kesehatan telah menyelenggarakan pilot proyek deteksi dini kanker leher rahim di 6 Kabupaten yaitu Deli Serdang (Sumatera Utara), Gresik (Jawa Timur), Kebumen (Jawa Tengah), Gunung Kidul (DI Yogyakarta), Karawang (Jawa Barat), dan Gowa (Sulawesi Selatan). Deteksi dini kanker leher rahim dilakukan dengan menggunakan metode Inspeksi Visual dengan Asam Asetat (IVA) (Depkes RI, 2008).

Menurut Profil Dinas Kesehatan Deli Serdang tahun 2009, Surveilans Terpadu Penyakit Bidang Pencegahan dan pemberantasan Penyakit (P2P) Dinas Kesehatan Kabupaten Deli Serdang mencatat ada 9 kasus kanker leher rahim yang dilaporkan oleh RSU Lubuk Pakam Deli Serdang. Kasus ini ditambah dengan 4 kasus kanker leher rahim diperoleh dari skrining IVA yang dilakukan di 8 Puskesmas Pilot Project. Jumlah perempuan yang berusia 30-50 tahun adalah 48.802 orang. Dengan demikian, di Deli Serdang terdapat 13 kasus kanker leher rahim $(0,027$ $\%)$ atau 27 per 100.000 perempuan yang berusia 30-50 tahun (Chandra S, 2011).

Di samping itu penulis melakukan survey awal di Desa Delitua Lingkungan 3 Kecamatan Delitua Kabupaten Deli Serdang. Dari 10 orang ibu Pasangan Usia Subur (PUS) yang saya wawancarai secara langsung, ternyata mereka mengatakan bahwa mereka belum pernah melakukan pemeriksaan IVA. Hal ini disebabkan karena kurangnya pemahaman mereka terhadap deteksi dini kanker seviks.
Berdasarkan uraian diatas, maka penulis tertarik untuk melakukan penelitian mengenai "hubungan tingkat pengetahuan ibu PUS tentang kanker serviks terhadap sikap untuk melakukan tes IVA (Inspeksi Visual dengan Asam Asetat) di Desa Delitua Lingkungan 3 Kecamatan Delitua Kabupaten Deli Serdang Tahun 2015”.

\section{Perumusan Masalah}

Berdasarkan latar belakang di atas maka perumusan masalah dalam penelitian ini adalah : "Bagaimana hubungan tingkat pengetahuan ibu PUS tentang kanker serviks terhadap sikap untuk melakukan tes IVA (Inspeksi Visual dengan Asam Asetat) di Desa Delitua Lingkungan 3 Kecamatan Delitua Kabupaten Deli Serdang tahun 2015?”

\section{Tujuan}

Untuk mengetahui hubungan tingkat pengetahuan ibu PUS tentang kanker serviks terhadap sikap untuk melakukan tes IVA di Desa Delitua Lingkungan 3 Kecamatan Delitua Kabupaten Deli Serdang tahun 2015.

\section{Variabel Independen}

\section{Variabel Dependen}

Dari kerangka konsep diatas, variabel independen dalam penelitian ini yaitu pengetahuan ibu PUS tentang pengertian, penyebab, tanda dan gejala kanker serviks, pencegahan, dan diagnosa kanker serviks. Sedangkan variabel dependen dalam penelitian ini yaitu sikap untuk melakukan tes IVA (Inspeksi Visual dengan Asam Asetat).

\section{Hipotesis Penelitian}

Hipotesis penelitian merupakan jawaban sementara terhadap rumusan masalah penelitian. Berdasarkan rumusan masalah dan kerangka pemikiran penelitian, maka hipotesis penelitian ini adalah (Ha) "ada hubungan antara tingkat pengetahuan ibu PUS tentang kanker serviks terhadap sikap untuk melakukan tes IVA”.

\section{Jenis Penelitian}

Jenis penelitian yang digunakan adalah penelitian bersifat deskriptif analitik dengan desain "cross sectional", dimana variabel independen dan variabel dependen diteliti secara bersamaan dan dalam satu waktu bertujuan untuk mengetahui hubungan tingkat pengetahuan ibu tentang kanker serviks dengan sikap ibu untuk melakukan tes IVA di Desa Delitua Lingkungan 3 Kecamatan Delitua Kabupaten Deli Serdang tahun 2015.

\section{Lokasi Penelitian}

Penelitian ini dilakukan di Desa Delitua Lingkungan 3 Kecamatan Delitua Kabupaten Deli serdang, alasannya karena:

a. Ditemukan masih rendahnya jumlah ibu PUS untuk melakukan tes IVA. 
b. Belum pernah dilakukan penelitian yang sama di lingkungan 3.

c. Jumlah populasi memenuhi untuk penelitian.

\section{Populasi}

Populasi dalam penelitian ini adalah seluruh ibu Pasangan Usia Subur (PUS) yang bertempat tinggal di Desa Delitua Lingkungan 3 Kecamatan Delitua Kecamatan Delitua Kabupaten Deli Serdang sebanyak 128 orang.

\section{Sampel}

Pengambilan sampel dengan rumus acak sistematis (sistematic random sampling) yaitu dengan teknik mengundi/mengacak responden pertama, responden selanjutnya diambil secara sistematis sesuai dengan jarak interval yang dihitung. Besarnya jumlah sampel dapat dihitung dengan menggunakan rumus:

$$
\mathrm{n}=\frac{N}{1+N\left(d^{2}\right)}
$$

Keterangan

$\mathrm{n}$ : besarnya sampel

$\mathrm{N}$ : besarnya populasi

$\mathrm{d}$ : tingkat kepercayaan $(0,1)$

Besarnya populasi sebanyak 128 orang, maka:

$$
\mathrm{n}=\frac{N}{1+N\left(d^{2}\right)}
$$

$\mathrm{n}=\frac{128}{1+128\left(0,1^{2}\right)}$

$\mathrm{n}=\frac{128}{1+1,28}$

$\mathrm{n}=\frac{128}{2,28}$

$n=56,14$

$\mathrm{n}=56$

Dalam menggunakan rumus di atas, pengambilan sampel dilakukan dengan cara acak sistematis yaitu seluruh populasi diberi nomor urut kemudian diambil sampel dengan interval (i) tertentu dimana besarnya sampel ditentukan dengan membagi populasi $(\mathrm{N})$ dengan jumlah sampel yang diinginkan.

$$
\begin{aligned}
& \mathrm{i}=\frac{\mathrm{N}}{\mathrm{n}} \\
& \mathrm{i}=\frac{128}{56} \\
& \mathrm{i}=2,2 \\
& \mathrm{i}=2
\end{aligned}
$$

Untuk memperkecil tingkat kesalahan dalam penelitian ini maka jumlah sampel menjadi 56 orang dengan interval 2 dan pengambilan sampel dilakukan secara acak sederhana yang dimulai dari 1 s/d 128 selanjutnya diambil kelipatan 2, yakni 1, 3,5,7,9,11, s/d tercapai sampel sebanyak 56. Menentukan sampelnya yaitu dengan memberi tanda pada rumah ibu PUS yang telah dikunjungi sehingga tidak ada rumah yang berulang dikunjungi.

\section{Jenis Data}

Jenis data yang digunakan adalah data primer dalam bentuk kuesioner yang diperoleh langsung dari jawaban responden dan data sekunder dengan meminta data jumlah penduduk pasangan usia subur di Desa Delitua Lingkungan 3 Kecamatan Delitua Kabupaten Deli Serdang.

\section{Cara Pengumpulan Data}

Pengumpulan data dilakukan dengan cara pengisian kuesioner oleh responden. Peneliti membagikan kuesioner dengan cara mengunjungi rumah responden. Sebelum responden menjawab kuesioner tersebut, terlebih dahulu peneliti memberikan penjelasan cara pengisian kuesioner tersebut dan meminta kesediaan responden untuk menandatangi surat pernyataan persetujuan menjadi responden penelitian.

Kuesioner yang digunakan untuk mengumpulkan data tentang tingkat pengetahuan ibu PUS tentang kanker serviks terhadap sikap untuk melakukan tes IVA, yang terdiri dari 30 soal, kisi-kisi kuesioner mengarah kepada: pengetahuan ibu tentang kanker serviks dan sikap ibu untuk melakukan tes IVA.

\section{Analisis Data} berikut:

Analisa data yang akan dilakukan adalah sebagai

a. Analisa Data Univariat

Analisis data univariat ini digunakan untuk mendapatkan distribusi frekuensi atau besarnya proporsi dari variabel independen dan variabel dependen sehingga dapat diketahui variasi dari masing-masing variabel.

b. Analisa Data Bivariat

Analisis data bivariat ini digunakan untuk melihat hubungan antara pengetahuan ibu tentang kanker serviks dengan sikap ibu untuk melakukan test IVA dengan menggunakan uji chi square dan derajat kemaknaan $\alpha=$ 0,05.Hasil uji chi-square menyatakan Ho ditolak jika nilai $\mathrm{P}<0,05$ artinya ada hubungan yang signifikan sedangkan jika nilai $\mathrm{P}>0,005$, ini menunjukkan hipotesa nol (Ho) diterima artinya tidak ada hubungan yang signifikan.

\section{Hasil}

Pada bab ini akan diuraikan mengenai hasil penelitian dan pembahasan tentang "Hubungan tingkat pengetahuan ibu PUS tentang kanker serviks terhadap sikap untuk melakukan tes IVA di desa Delitua lingkungan 3 kecamatan Delitua kabupaten Deli Serdang tahun 2015” pada 56 responden. Hasil penelitian ini akan dibagi dalam 2 bagian, yaitu data umum dan data khusus.

Data umum akan menampilkan karakteristik responden yang meliputi umur dan pendidikan. Data khusus meliputi hasil penelitian yang dimasukkan dalam distribusi frekuensi dan interpretasi data antara variabel independen dengan dependen untuk mengetahui hubungan antara variabel.

\section{Umur Responden}

Data mengenai usia responden dapat dilihat pada tabel 4.1 sebagai berikut: 
Tabel 4.1

Distribusi Frekuensi Umur Responden Di Desa Delitua Lingkungan 3Kecamatan Delitua Kabupaten Deli Serdang Tahun 2015

\begin{tabular}{|c|c|c|c|}
\hline \multirow{2}{*}{ No } & \multirow{2}{*}{ Umur } & \multicolumn{2}{|c|}{ Jumlah } \\
\cline { 3 - 4 } & & $\mathbf{F}$ & $\mathbf{\%}$ \\
\hline 1. & $<20$ tahun & 2 & 3,6 \\
\hline 2. & $20-35$ tahun & 33 & 58,9 \\
\hline 3. & $>35$ tahun & 21 & 37,5 \\
\hline \multicolumn{2}{|c|}{ Jumlah } & $\mathbf{5 6}$ & $\mathbf{1 0 0}$ \\
\hline
\end{tabular}

Berdasarkan tabel 4.1 diketahui bahwa dari 56 responden mayoritas berusia 20-35 tahun yaitu sebanyak 33 orang $(58,9 \%)$ dan minoritas berusia $<20$ tahun sebanyak 2 orang (3,6\%).

\section{Pendidikan Responden}

Data mengenai pendidikan responden dapat dilihat pada tabel 4.2 sebagai berikut:

Tabel 4.2

Distribusi Frekuensi Pendidikan Responden Di Desa Delitua Lingkungan 3 Kecamatan Delitua Kabupaten Deli Serdang Tahun 2015

\begin{tabular}{|c|l|c|c|}
\hline \multirow{2}{*}{ No } & \multirow{2}{*}{ Pendidikan } & \multicolumn{2}{|c|}{ Jumlah } \\
\cline { 3 - 4 } & & $\mathbf{F}$ & $\mathbf{\%}$ \\
\hline 1. & Dasar & 15 & 26,8 \\
\hline 2. & Menengah & 30 & 53,6 \\
\hline 3. & Tinggi & 11 & 19,6 \\
\hline \multicolumn{2}{|c|}{ Jumlah } & $\mathbf{5 6}$ & $\mathbf{1 0 0}$ \\
\hline
\end{tabular}

Berdasarkan tabel 4.2 diketahui bahwa dari 56 responden mayoritas berpendidikan menengah yaitu sebanyak 30 orang $(53,6 \%)$ dan minoritas berpendidikan tinggi sebanyak 11 orang (19,6\%).

\section{Pengetahuan Ibu}

Pengetahuan ibu yang dijadikan responden bevariasi, mulai dari pengetahuan baik, cukup, dan kurang, yang dapat dilihat pada tabel berikut:

Tabel 4.3.

Distribusi Pengetahuan Ibu PUS Tentang Kanker Serviks

Di Desa Delitua Lingkungan 3 Kecamatan Delitua Kabupaten Deli Serdang Tahun 2015

\begin{tabular}{|l|l|c|c|}
\hline No & Pengetahuan & Jumlah & Persentase \\
\hline 1 & Baik & 9 & 16,1 \\
\hline 2 & Cukup & 15 & 26,8 \\
\hline 3 & Kurang & 32 & 57,1 \\
\hline \multicolumn{2}{|c|}{ Jumlah } & $\mathbf{5 6}$ & $\mathbf{1 0 0}$ \\
\hline
\end{tabular}

Berdasarkan tabel 4.3 diketahui bahwa dari 56 responden mayoritas berpengetahuan kurang yaitu sebanyak 32 orang $(57,1 \%)$ dan minoritas berpengetahuan baik sebanyak 9 orang (16,1\%).
Sikap Ibu

Sikap ibu untuk melakukan tes IVA di kategorikan dalam sikap positif dan sikap negatif, dapat dilihat pada tabel berikut:

Tabel 4.4.

Distribusi Sikap Ibu PUS Untuk Melakukan Tes IVA Di Desa Delitua Lingkungan 3 Kecamatan Delitua

Kabupaten Deli Serdang Tahun 2015

\begin{tabular}{|l|l|c|c|}
\hline No & Sikap & Jumlah & Persentase \\
\hline 1 & Positif & 35 & 62,5 \\
\hline 2 & Negatif & 21 & 37,5 \\
\hline \multicolumn{2}{|c|}{ Jumlah } & $\mathbf{5 6}$ & $\mathbf{1 0 0}$ \\
\hline
\end{tabular}

Berdasarkan tabel 4.4 diketahui bahwa dari 56 responden mayoritas bersikap positif yaitu sebanyak 35 orang (62,5\%) dan minoritas bersikap negatif sebanyak 21 orang (37,5\%).

\section{Hubungan Pengetahuan Dengan Sikap Untuk Melakukan Tes IVA}

Distribusi hubungan pengetahuan ibu PUS tentang kanker serviks terhadap sikap untuk melakukan tes IVA, dapat dilihat pada tabel berikut:

Tabel 4.5.

Distribusi Hubungan Pengetahuan Ibu PUS Tentang Kanker Serviks Terhadap Sikap Untuk Melakukan

Tes IVA Di Desa Delitua Lingkungan 3 Kecamatan Delitua Kabupaten Deli Serdang Tahun 2015

\begin{tabular}{|c|c|c|c|c|c|c|c|c|}
\hline \multirow{3}{*}{ Pengetahuan } & \multicolumn{4}{|c|}{ Sikap } & \multirow{2}{*}{\multicolumn{2}{|c|}{ Jumlah }} & \multirow{3}{*}{$X^{2}$} & \multirow{3}{*}{$\mathbf{P}$} \\
\hline & \multicolumn{2}{|c|}{ Positif } & \multicolumn{2}{|c|}{ Negatif } & & & & \\
\hline & $\mathbf{N}$ & $\%$ & $\mathbf{N}$ & $\%$ & $\mathbf{N}$ & $\%$ & & \\
\hline Baik & 9 & 16,1 & - & - & 9 & 16,1 & \multirow{4}{*}{15,67} & \multirow{4}{*}{0,000} \\
\hline Cukup & 13 & 23,2 & 2 & 3,6 & 15 & 26,8 & & \\
\hline Kurang & 13 & 23,2 & 19 & 33,9 & 32 & 57,1 & & \\
\hline Jumlah & 35 & 62,5 & 21 & 37,5 & 56 & 100 & & \\
\hline
\end{tabular}

Berdasarkan tabel 4.5 diketahui bahwa dari 56 responden mayoritas berpengetahuan kurang dan bersikap negatif yaitu sebanyak 19 orang (33,9\%) dan minoritas berpengetahuan cukup dan bersikap negatif sebanyak 2 orang $(3,6 \%)$.

Hasil uji chi-square menyatakan Ho ditolak jika probablitas $<0,05$. Hasil analisa dengan uji chi-square $d(f)=2$ maka diperoleh $X^{2}$ hitung $(15,67)>X^{2}$ tabel $(4,605)$ dan nilai probabilitas ( $p=0,000<0,05)$ maka Ho ditolak dan Ha diterima, artinya terdapat hubungan yang signifikan antara pengetahuan dengan sikap Ibu PUS.

\section{Pembahasan}

Hubungan Pengetahuan Ibu PUS Dengan Sikap untuk melakukan tes IVA

Berdasarkan hasil analisa data secara umum pengetahuan ibu tentang kanker serviks dari 56 responden, yang berpengetahuan baik sebanyak 9 orang $(16,1 \%)$, berpengetahuan cukup sebanyak 15 orang (26,8\%), dan yang berpengetahuan kurang sebanyak 32 orang $(57,1 \%)$.

Dari data tersebut dapat diketahui bahwa pengetahuan ibu tentang kanker serviks di Desa Delitua lingkungan 3 kecamatan Delitua kabupaten Deli Serdang 
mayoritas adalah berpengetahuan kurang sebanyak 32 orang $(57,1 \%)$. Dari kenyataan tersebut menunjukkan bahwa ibu PUS tidak mampumenjawab pertanyaan dalam bentuk kuesioner tentang kanker serviks dengan benar yang meliputi pengertian kanker serviks, penyebab kanker serviks, tanda dan gejala kanker serviks, pencegahan dan diagnosa kanker serviks.

Berdasarkan hasil penelitian yang saya dapat di desa Delitua lingkungan 3 kecamatan Delitua kabupaten Deli Serdang tidak sesuai dengan yang dikemukakan oleh Notoatmodjo yang mengatakan bahwa yaitu dengan bertambahnya usia seseorang, maka pemikirannya akan semakin berkembang sesuai dengan pengetahuan yang pernah didapat. Dalam hal ini ibu PUS yang berpengetahuan kurang yaitu 57,1\% lebih mendominasi terhadap usia responden 20-35 tahun. Ternyata dari hasil penelitian yang saya dapat faktor pendidikan ibu PUS juga tidak berpengaruh terhadap pengetahuan ibu PUS tentang kanker serviks. Hal ini tidak sesuai dengan pernyataan Notoatmodjo yang mengatakan semakin tinggi tingkat pendidikan seseorang maka akan semakin tinggi pula tingkat pengetahuan yang dimiliki seseorang sedangkan orang yang memiliki pendidikan rendah pengetahuannya tidak sebaik yang memiliki pendidikan yang tinggi. Dimana ibu yang memiliki pengetahuan kurang yaitu $57,1 \%$ lebih mendominasi terhadap pendidikan ibu menengah (SMA/sederajat).

Kemungkinan faktor lain yang mempengaruhi pengetahuan seperti pekerjaan, lingkungan dan sosial budaya. Dimana seseorang yang bekerja pengetahuannya akan lebih luas dari pada seseorang yang tidak bekerja karena dengan berkerja seseorang akan banyak mendapat informasi dan pengalaman. Seseorang yang hidup dalam lingkungan yang berpikir luas maka pengetahuannya akan lebih baik dari pada orang yang tinggal di lingkungan yang berpikir sempit. Dan seseorang yang hidup dalam heterogenitas sosial dan budaya yang berpengaruh turun menurun yang tinggi, maka pengetahuannya akan lebih baik dari pada orang yang tinggal di heterogenitas yang rendah yang berpikiran sempit.

Data mengenai sikap ibu untuk melakukan tes IVA di desa Delitua lingkungan 3 kecamatan Delitua kabupaten Deli Serdang didapatkan bahwa ibu yang memiliki sikap positif sebanyak 35 orang (62,5\%) sedangkan yang mempunyai sikap negatif sebanyak 21 orang $(37,5 \%)$. Sebagian besar ibu yang memiliki sikap positif dibuktikan dengan kemampuan mengisi kuesioner yang berupa pernyataan favorable dan unfavorabel.

Hal ini menunjukkan bahwa sebagian besar responden bertindak atau menerapkan konsep teori yang didapat pada kondisi yang sebenarnya. Hal ini sesuai dengan teori menurut Notoatmodjo bahwa dalam penentuan sikap yang utuh, pengetahuan, pikiran, keyakinan dan emosi yang memegang peranan penting (Notoatmodjo, 2010)

Dimana ibu PUS yang bersikap negatif masih dikatakan tergolong besar yaitu 37,5 \%. Faktor yang mempengaruhi sikap negatif ini pada umumnya dikarenakan adanya perubahan sikap ibu PUS yang terjadi perlahan-lahan seiring dengan bertambahnya pengetahuan dan informasi yang didapatkan. Hal ini sesuai dengan teori yang dikemukakan oleh Azwar bahwa faktor yang mempengaruhi sikap salah satunya pengalaman pribadi apa yang telah dan sedang kita alami akan ikut membentuk dan mempengaruhi penghayatan kita terhadap stimulus sosial. Tanggapan akan menjadi salah satu dasar terbentuknya sikap. Untuk dapat mempunyai tanggapan dan penghayatan, seseorang harus mempunyai pengalaman yang berkaitan dengan obyek psikologis. Sehubungan dengan hal itu mengatakan bahwa tidak adanya pengalaman sama sekali dengan suatu obyek psikologis cenderung akan membentuk sikap negatif terhadap obyek tersebut.

Pada hasil analisa data hubungan antara pengetahuan dengan sikap ibu untuk melakukan tes IVA dengan menggunakan uji Chi-square didapatkan nilai signifikan 0,000 dimana angka ini kurang dari batas signifikan yaitu $\mathrm{P}=0,05$, maka dapat disimpulkan bahwa terdapat hubungan antara pengetahuan ibu tentang kanker serviks dengan sikap ibu untuk melakukan tes IVA di desa Delitua Lingkungan 3 kecamatan Delitua kabupaten Deli Serdang.

Hubungan pengetahuan ibu tentang kanker serviks dengan sikap untuk melakukan tes IVA ini dapat dibuktikan dengan ibu PUS yang mempunyai kriteria pengetahuan baik dan cukup cenderung memiliki sikap yang positif dibanding sikap negatif. Sedangkan kriteria pengetahuan kurang cenderung lebih memiliki sikap negatif (tabel 4.5). Maka dapat disimpulkan bila ibu PUS paham dan tahu tentang kanker serviks maka ibu PUS bersedia untuk melakukan tes IVA. Sedangkan ibu yang tidak paham tentang kanker serviks maka ibu PUS tidak bersedia untuk melakukan tes IVA.

Hal ini sesuai dengan hasil penelitian seorang mahasiswa yang berasal dari akademi kebidanan di Malang yang berjudul "hubungan antara tingkat pengetahuan ibu tentang kanker serviks dengan sikap ibu untuk melakukan tes IVA", yang mengatakan bahwa dengan menggunakan uji Chi-square didapatkan nilai signifikan $(P=0,001<0,05)$, mempunyai hubungan antara pengetahuan dengan sikap ibu untuk melakukan tes IVA (Angiesudibyo, 2011).

Berdasarkan jurnal ilmiah kesehatan keperawatan STKes (2009), kanker serviks adalah penyakit kanker yang menyerang leher rahim wanita. Penyakit ini merupakan penyakit keganasan yang dapat menyebabkan kematian akibat kesadaran untuk memeriksakan diri dirasakan sangat rendah. Hal ini tidak terlepas dari kurangnya pengetahuan mengenai kanker serviks. Indikasinya lebih dari $70 \%$ penderita yang datang ke rumah sakit sudah pada kondisi lanjut (Jurnal Ilmiah Kesehatan, 2009).

Menurut Soekidjo Notoatmodjo bahwa perilaku yang didasari oleh pengetahuan akan lebih langgeng daripada perilaku yang tidak didasari oleh pengetahuan. Oleh karena itu sangat penting untuk memberikan penyuluhan ataupun konseling untuk menambah pengetahuan seseorang (Notoatmodjo, 2010). Sikap juga tidak hanya dipengaruhi oleh pengetahun akan tetapi ada beberapa faktor lain yang mempengaruhi sikap antara lain 
pengalaman pribadi, kebudayaan, media massa, lembaga pendidikan dan lembaga agama (Azwar, 2003).

Berdasarkan hasil penelitian yang didapat, ibu PUS merasa tidak perlu memeriksakan diri sejak dini hal ini disebabkan karena ibu PUS belum mengetahui tentang pengertian kanker serviks, penyebab kanker serviks, tanda dan gejala kanker serviks, pencegahan dan diagnosa kanker serviks yang mengakibatkan wanita terlambat menyadari adanya kanker leher rahim sehingga meningkatkan angka morbiditas dan mortalitas kanker leher rahim, padahal kanker leher rahim sebenarnya dapat disembuhkan $100 \%$ bila ditemukan sejak dini dan ditangani segera. Hal ini dikarenakan perjalanan infeksi HPV (Human Papiloma Virus) sampai menjadi kanker membutuhkan waktu yang cukup lama, namun kanker leher rahim ini tidak menunjukkan gejala kesakitan sama sekali pada stadium dini. Pada wanita yang tidak pernah melakukan deteksi dini, kanker cenderung ditemukan pada stadium lanjut, dimana kanker sudah sulit disembuhkan. Itulah sebabnya deteksi dini kanker leher rahim sangat penting dilakukan.

\section{Simpulan}

Berdasarkan hasil penelitian yang dilakukan mengenai "Hubungan tingkat pengetahuan ibu PUS tentang kanker serviks terhadap sikap untuk melakukan tes IVA di desa Delitua Lingkungan 3 Kecamatan Delitua Kabupaten Deli Serdang tahun 2015” dapat disimpulkan sebagai berikut:

1. Tingkat pengetahuan dari 56 responden mayoritas berpengetahuan kurang $(57,1 \%)$, dan minoritas berpengetahuan baik $(16,1 \%)$ tentang kanker serviks.

2. Sikap ibu PUS untuk melakukan tes IVA dari 56 responden mayoritas bersikap positif (62,5\%), dan minoritas bersikap negatif (37,5\%).

3. Hasil uji chi-square diperoleh nilai probabilitas ( $\mathrm{p}=$ $0,000<0,05)$, artinya terdapat hubungan yang bermakna antara pengetahuan ibu PUS tentang kanker serviks dengan sikap untuk elakukan tes IVA.

\section{Saran}

Saran yang dapat penulis sampaikan adalah:

\section{Bagi Kader}

Agar memberikan penyuluhan tentang kanker serviks dan pencegahan kanker serviks sehingga meningkatkan kesadaran ibu untuk melakukan tes IVA.

2. Bagi Tenaga Kesehatan

Bagi tenaga kesehatan yang sudah terlatih untuk pemeriksaan IVA agar memberikan pelayanan IVA di tempat mereka bekerja.

3. Bagi Peneliti Lanjutan

Sebagai bahan masukan dan perbandingan untuk dapat melakukan penelitian lanjutan dengan memperbanyak sampel dan menggali variabel lain yang berhubungan.

\section{DAFTAR PUSTAKA}

Admin, 2012, Kanker Serviks, (http://www.pembalutsehatanion.com). Diakses tanggal 04 Maret 2012.

Azwar saifudin, 2007. Sikap Manusia Teori dan Pengukurannya edisi 2, Pustaka Pelajar, Yogyakarta.

Depkes, 2011, Jika Tidak Dikendalikan 26 Juta Orang di Dunia Menderita Kanker, (www.depkes.go.id). Diakses tanggal 06 April 2012.

Deherba, 2010, Statistik Penderita Kanker di Indonesia, (www.deherba.com). Diakses tanggal 08 April 2012.

Eva ellya sibagariang dkk, 2010. Kesehatan Reproduksi Wanita, CV Trans Info Media, Jakarta.

Harian Sumut Pos, 2011. Sumut Dominasi Kanker Leher Rahim, (www.medanpunya.com/medan/17219). Diakses tanggal 06 April 2012.

Info ceria, 2010.Mengenal Kanker Serviks Penyakit Kanker Serviks, (www.infoceria.com). Diakses tanggal 08 April 2012.

Machfoedz ircham, 2009. Metodologi Penelitian, Fitramaya, Yogyakarta.

Muchlis ramli, Umbas rainy, Panigoro Sonar, 2005. Deteksi Dini Kanker, FKUI, Jakarta.

Mulyani anik sri, 2006. Hubungan antara Pengetahuan dengan Sikap Tentang Cara Menyusui yang Benar,KTI akbid Widyagama Husada Malang, Malang.

Notoatmodjo, S, 2007. Kesehatan Masyarakat Ilmu dan Seni, Rineka Cipta, Jakarta.

2010. Promosi Kesehatan dan Ilmu Prilaku, Rineka Cipta, Jakarta.

2010. Metodologi Penelitian Kesehatan, Rineka CIpta, Jakarta.

Politeknik Kesehatan, 2006. Panduan Penyusunan KTI, Medan.

Rasjidi imam, 2010.100 question and answer kanker serviks, PT Elex Media Komputindo, Jakarta.

Yohana, Yovita, Yessica, 2011. Infokus Reproduksi Wanita Kehamilan dan Persalinan, Garda Media, Jakarta.

Yusrawati, 2010. Diktat Biostatistika, Politeknik Kesehatan Medan.

Widyastuti yani dkk, 2009. Kesehatan Reproduksi, Fitramaya, Yogyakarta. 